\title{
SH3D19 wt Allele
}

National Cancer Institute

\section{Source}

National Cancer Institute. SH3D19 wt Allele. NCI Thesaurus. Code C98006.

Human SH3D19 wild-type allele is located in the vicinity of 4 q31.3 and is approximately $108 \mathrm{~kb}$ in leng th. This allele, which encodes SH3 domain-containing protein 19, plays a role in both protein-protein interactions and protein localization to the plasma membrane. A translocation involving this gene and the RUNX1 gene may be associated with acute myeloid leukemia. 